\title{
Selecting phototrophic species of native biocrusts in arid and semi-arid regions
}

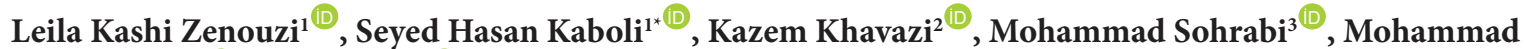

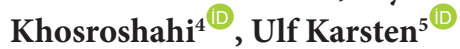 \\ ${ }^{1}$ Faculty Desert Studies, Semnan University, Semnan, Iran \\ ${ }^{2}$ Department of Soil Biology, Soil and Water Research Institute, Agricultural Research Education and Extension Organization (AREEO), \\ Tehran, Iran \\ ${ }^{3}$ Iranian Research Organization for Science and Technology, Tehran, Iran \\ ${ }^{4}$ Desert Research Division, Research Institute of Forests and Rangelands, Agricultural Research Education and Extension Organization \\ (AREEO), Tehran, Iran \\ ${ }^{5}$ Institute of Biological Sciences, Applied Ecology \& Phycology, University of Rostock, Germany
}

\begin{abstract}
Background: Biological soil crusts (BSCs) that are able to produce sticky extracellular polymeric substances (EPS) play an important role in the formation of soil aggregates, thereby, reducing soil erosion. In this study, experiments were undertaken to identify biocrust species that produce EPS, in order to combat desertification in the Sejzi desert of Iran.

Methods: A biocrust distribution map of Sejzi plain was prepared using Landsat 8 OLI images, then, various sampling points were selected. Some physicochemical parameters of samples from lichendominated and non-biocrusted areas were measured. The relationship between soil parameters and biocrusts presence was confirmed based on the Pearson's correlation coefficient and principal component analysis (PCA) method. The type of chemical compounds in the soil content were determined via Fourier transform infrared spectroscopy (FTIR), including polysaccharides. To estimate the degradability of polysaccharides, each soil sample was placed under defined UV-B radiation for 24 , 48 , and 72 hours at three replications.

Results: There was no significant correlation between moss and lichen species with the amount of EPS (\%) values and various occurring cyanolichen species in three biocrusted soil samples, which included Collema coccophorum, Collema tenax, Peccania terricola, and Placidium squamulosum. It was speculated that these polysaccharides were produced by the photobiotic partners (microalgae or cyanobacteria) and secreted to the soil.

Conclusion: According to the results, the cyanobacteria species of biocrusted samples might have high potential to combat desertification and soil stabilization in Sejzi desert.

Keywords: Cyanobacteria, Fourier transform infrared, Lichens, Polysaccharides, Sejzi plain, Iran

Citation: Kashi Zenouzi L, Kaboli SH, Khavazi K, Sohrabi M, Khosroshahi M, Karsten U. Selecting phototrophic species of native biocrusts in arid and semi-arid regions. Environmental Health Engineering and Management Journal 2021; 8(3): 153-167. doi: 10.34172/EHEM.2021.19.
\end{abstract}

\section{Article History:}

Received: 6 February 2021

Accepted: 17 May 2021

ePublished: 30 August 2021

\section{Introduction}

Biological soil crusts (BSCs) are an important vegetation type in drylands, which enrich the upper millimeters of the soil with organic matter and nutrients, thereby, initiating biogeochemical cycles (1). Biocrusts play multiple essential roles in ecosystem functions $(2,3)$, including soil stabilization due to their dense network of algal/cyanobacterial filaments in combination with sticky extracellular polymeric substances (EPS), that are secreted as cellular sheaths and mucilage (4-6).

These communities effectively stabilize the soil surface, impeding the drift and migration of soil particles by wind
(7-9) and water (10). The EPS accumulate in a threedimensional extracellular polymeric matrix constituted by fractions with different grades of gelation (11). This matrix is an important biocrust component that serves in a wide array of functions, from conferring stability and cohesion to the crust structure and maintaining the moisture against evapotranspiration, as well as the exchange of nutrients and minerals at the microscale $(11,12)$.

Lichen species appear to be one of the strongest predictors for biocrust community composition, and highly-structured lichen-associated bacterial communities (microbiome) reflect different functional 
roles in symbiosis with the host $(13,14)$. Differences in chemistry, structure, and growth of lichen-dominated biocrusts (e.g. crustose, foliose or fruticose lichens) also create a wide diversity of ecological niches for additional microorganisms (e.g. microalgae). Rhizobiales is typically the most abundant and taxonomically diverse order in lichen microbiomes $(14,15)$.

Biocrusts composed of lichens and cyanobacteria certainly secrete a wide variety of primary and secondary metabolites, such as oxalates, and other acid compounds, such as gyrophoric acid, lecanoric acid, and usnic acid (16-20), while the hydrophilic part of the lichens are typically composed of a large number of extracellular polysaccharides, that could also promote the growth of anaerobic bacteria (13), and some of these polysaccharides are of chemotaxonomic value (7). By applying chemical methods, it is still very difficult to distinguish to what extent soil polysaccharides are derived from plants, lichens or microorganisms (21). The soil with the lowest initial microbial biomass (lowest clay content) showed the highest polysaccharide enrichment, and the resulting fastest soil aggregate stabilizing effect is one of the highest ecological interest (22), concerning rehabilitation strategies in drylands and disturbed ecosystems. Most interesting, the stability of soil polysaccharides in its native state is not related to its chemical composition or structural complexity, but rather to its unavailability to soil microorganisms or their extracellular hydrolytic enzymes $(21,23)$.

The polysaccharides from Nostoc and other cyanobacterial strains that are photobionts of cyanolichens are typically composed of different monosaccharides such as hexoses (glucose, galactose, mannose), pentoses (ribose, xylose, arabinose), deoxy sugars (fucose and rhamnose), and acidic hexoses (glucuronic and galacturonic acid) (24). There are some evidence indicating that increases in the rhamnose or mannose proportion of polysaccharides lead to higher soil aggregate stability. Several microbial polysaccharides are already highly effective soil-binding agents at very low concentrations (25). More sensitive detection methods seemed necessary to analyze all of the individual sugars also in the lowest concentrations, which may play a role as soil-binding agents (21). The aggregate-stabilizing effectiveness is more related to the molecular weight than to the chemical composition of polysaccharides (26). The biosynthesis of extracellular polysaccharides in cyanobacteria is induced by UV-B radiation. Fluence rates of UV-B which are within the magnitude of natural solar radiation induce a cascade of physiological and biochemical responses in Nostoc commune. In its natural habitat, Nostoc has to cope with high solar radiation under often dry conditions, in which photodamage cannot be efficiently repaired (27), and hence, extracellular polysaccharides are supposed to contribute to stress tolerance.
The study aimed to determine the most suitable cyanolichen species of native biocrusts in arid and semiarid regions of Sejzi desert (Iran) that produced high amounts of extracellular polysaccharides and are resistant to UV-B radiation. The soil carbohydrate measurements were designed in such a way that samples with the highest carbohydrate values were selected for the identification and isolation of biocrust lichen species. The hypothesis of this study was that polysaccharides produced by biocrusts, in particular by cyanolichens, stabilize the soil, and this biological activity can be applied to propagate biocrust species in order to combat desertification and improve soil stabilization in Sejzi desert (Iran).

\section{Materials and Methods Sampling}

The soil samples were prepared form Sajzi desert which is the central desert of Iran, Isfahan ( $52^{\circ} 27^{\prime} 41^{\prime \prime}-51^{\circ} 52^{\prime} 32^{\prime \prime}-\mathrm{E}$, $32^{\circ} 33^{\prime} 31^{\prime \prime}-32^{\circ} 55^{\prime} 01^{\prime \prime} \mathrm{N}$ ). This desert is located at 1680 $\mathrm{m}$ above sea level, with the average slope of $1.08 \%$, and sampling was performed in a 200 ha area (Figure 1). The climate of Sejzi plain is Mediterranean and dry based on the De Martonne and Ambreje classification method (28), with a mean annual precipitation of $106 \mathrm{~mm}$. The vascular vegetation is dominated by Artemisia siberi, Artemisia siberi-Noaea mucronata, Scariola orientalis, Salsola tomentosa, Alhagi persarum, Tamarix sp, and Anabasis haussknechtii.

Map of biocrust distribution was prepared using Landsat 8 OLI satellite data (Figure 1).

$\mathrm{BSCI}=\frac{1-L x\left|R_{\text {red }}-R_{\text {green }}\right|}{R_{\text {redgreenNIR }}}$

Where $R_{\text {RED }}$ and $R_{\text {GREEN }}$ are the reflectance of the green and red band, and $R_{\text {GREENREDNIR }}$ represents the mean reflectance in the red, green, and near-infrared band of the sensor. $L$ represents an adjustment parameter to amplify the absolute difference between $\mathrm{R}_{\text {GREEN }}$ and $\mathrm{R}_{\mathrm{RED}}$ (29).

Biocrust distribution map was validated, after a field surveying using a stratified random sampling method. The overall classification accuracy and overall Kappa statistics index were 0.9312 and $94 \%$, respectively. Afterwards, the maps of biocrust distribution, vegetation cover, and basic soil properties ( $\mathrm{pH}, \mathrm{EC}$, and soil texture) were blended in order to determine the same number of sampling points in each areal polygon, depending on the homogeneity of vegetation and soil properties. Because of the Mediterranean climate and the beginning of rainfall in the late October in Sejzi plain, resulting in increasing soil moisture and activity of BSCs, the first week of December was selected for sampling. However, only lichen-dominated and non-biocrusted soil samples were collected. In each of the homogenous areal polygons, biocrusted soils were randomly collected from $100 \mathrm{~m}$ transects at three locations every $30 \mathrm{~m}$ (Figure 1A). 


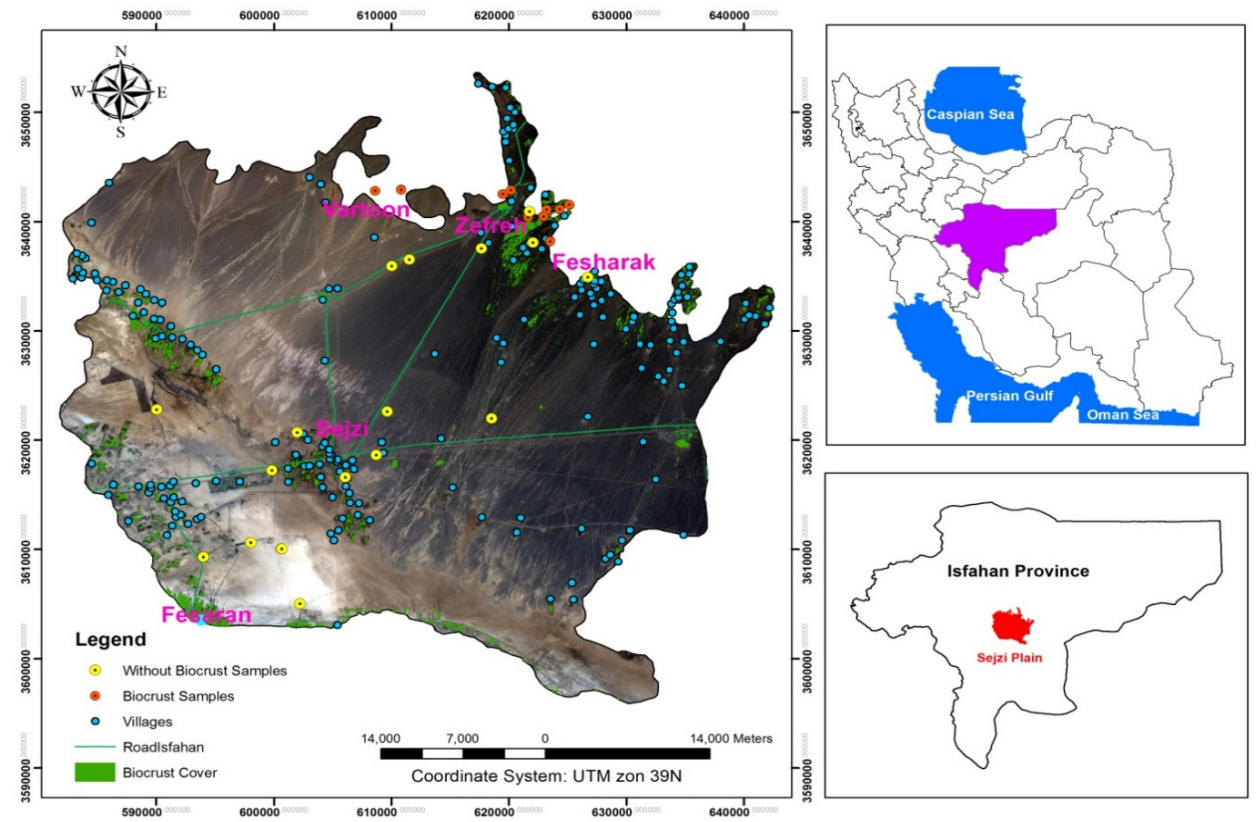

Figure 1. The study area and sampling points.

Soil samples were collected from areal polygon without biocrusts at a depth of $0-15 \mathrm{~cm}$ of topsoil surface (Figure 2A, C, E). Sampling depth depended on the biocrust cover thickness (Figure 2B, D, F). According to the thickness of biocrusts, soil samples were collected from $1-15 \mathrm{~cm}$ or 3-15 mm underneath the topsoil surface. Due to similar lichen species associated with biocrusts, three samples were collected with a distance of approximately $30 \mathrm{~m}$ from each sampling point, about $1 \mathrm{~kg}$ dry weight, and after mixing all three replicate samples, a homogeneous soil sample was prepared. Similar samples were collected from non-biocrusted areas. Finally, all of 40 soil samples ( 20 soil samples underneath lichen-dominated biocrusts and 20 non-biocrusted soil samples) were analyzed.

\section{Identification of cyanolichen dominated biocrusts}

The material was examined using standard microscopic techniques. Specimens were treated according to Obermayer (30) and determined by examination of their morphological properties using a microscope with magnifications of 40X and 100X, according to Dobson (31), Malcolm and Galloway (32), and Ryan et al (33). Anatomical properties were investigated by preparing thin layers of the thallus and fruiting bodies (34). Moreover, the chemical characters were investigated by spot tests. In special cases, thin layers chromatography were done. The principal determination keys used were according to Awasthi (35), Gaya (36), Krzewicka (37), Magnusson (38), Nash et al (39), Schultz et al (40), Sliwa (41), Smith et al (42), Temina et al (43). The specimens names were taxonomically considered via Index Fungorum (http:// www.speciesfungorum.org/names/names.asp) and Mycobank (44). The examined species were deposited in Iranian Research Organization for Science and Technology
(IROST) with its acronym ICH (Iranian Cryptogamic Herbarium).

\section{Physicochemical soil properties}

The following soil physicochemical properties were measured: $\mathrm{pH}$, electrical conductivity (EC) (45), $\mathrm{CaCo}_{3}$ (titration $\mathrm{NaOH} 1 \mathrm{~N}$ ), organic carbon content (OC\%) in $\%$ dry weight (46), soil texture (47), wet aggregate stability (WAS) (48), and mean weight diameter (MWD) (48). Dry grain size distribution curves were plotted according to the standard test method for sieve analysis of fine and coarse aggregates (ASTM C136), and the weight percentage of particles less than $0.84 \mathrm{~mm}$ were calculated as an index of soil wind erosion (49). To measure aggregate dry stability (ADS) index, $50 \mathrm{~g}$ of soil sample was passed through a series of standard mesh sizes, and soil particles were separated as the medium sand $(0.1-0.5 \mathrm{~mm})$ and fine sand (0.0105-0.07 $\mathrm{mm})$, and transferred into centrifuge tubes. They were centrifuged at 5,000 rpm for 5 minutes. The fine sand particles were bombarded with coarse sand and due to the force of friction at high speeds, they were crushed, and hence, the resistance of the aggregates was measured by the collision of the particles at high centrifugation speeds. Afterwards, the soil samples in the centrifuge tubes were added again to the same initial amount and again for $50 \mathrm{~g}$ of the soil, soil texture and the percentages of silt and clay in the samples were calculated according to Folk and Ward (47). According to the following formula, based on the difference between the values of silt and clay, the amount of ADS was calculated.

$$
A D S=\left|\frac{(A-B)}{(A+B)}\right|+\left|\frac{(C-D)}{(C+D)}\right|
$$

Where $A$ is the amount of silt in soil sample before 

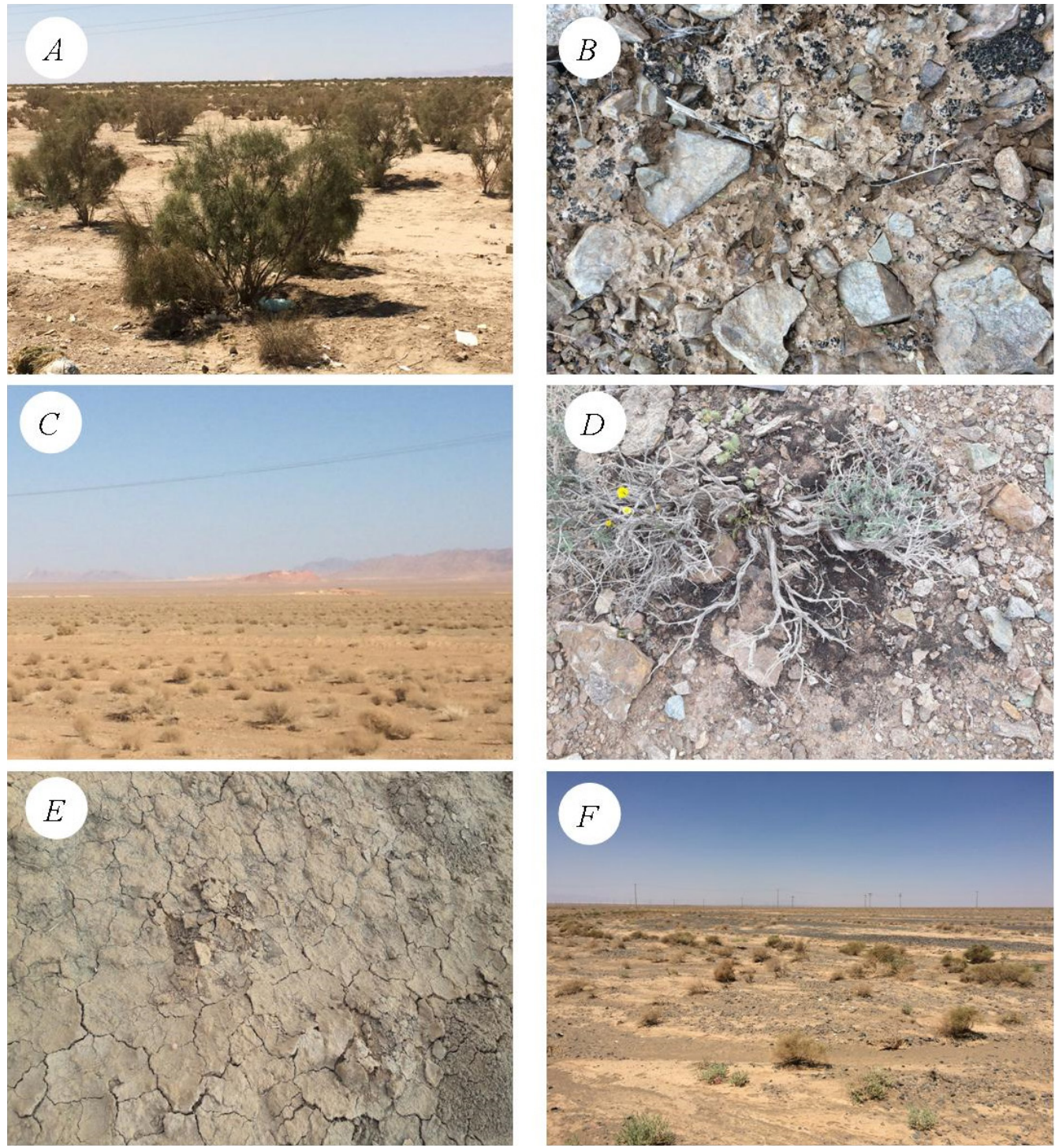

Figure 2. Study area (Sejzi plain, Iran) with different vegetation cover: A, C, and E are sampling points that all were non-biocrusted (where only soil samples were collected) and B, D, and F are where biocrust cover was found on the soil surface and biocrust and soil samples were collected.

centrifugation (\%), $B$ is the amount of clay in soil sample before centrifugation (\%), $C$ is the amount of silt in soil sample after centrifugation (\%), and $D$ is the amount of clay in soil sample after centrifugation (\%).

\section{Fourier Transform Infrared Spectroscopy (FTIR)}

To identify the type of organic compounds present in the soil samples, FTIR analysis was performed for samples which had higher OC (\%) values (23,50-54). Solid compounds should be tested in the form of a compact tablet or as a clearly deposited film. To prevent the scattering of IR rays, fine soil particles (silt and clay) were separated using a standard sieve (No. 200). Particles with a size less than $74 \mu \mathrm{m}$ were dried at 2 to $5 \mathrm{mg}$ in petri dishes for 24 hours at $150^{\circ} \mathrm{C}$ to eliminate the effect of water on the FTIR spectral reflection. Then, they were mixed with dry potassium bromide powder in a ratio of 2 to $200 \mathrm{mg}$ in an opal mortar, and prepared to a paste. Small tablets of 0.5 to $1.5 \mathrm{~mm}$ in diameter can be tested using an optical thickener. The mixture was squeezed into a clear tablet under a pressure of 10000 to 15000 psi. Using FB-IR MB-154 Bomem spectrometer and Bomem Easy software (ABB, Zurich, Switzerland), spectra for each sample were obtained.

\section{EPS quantification and analysis}

To measure the polysaccharides content in soil, they were first passed through standard No. 140 sieve (particle size less than $106 \mu \mathrm{m})(55)$. Two $g$ of soil was weighed into a $250 \mathrm{ml}$ Erlenmeyer flask and $4 \mathrm{~mL}$ of $0.5 \mathrm{~N} \mathrm{NaOH}$ was added to separate the soil particles completely $(55,56)$, and then, left for 3 hours in the lab.

Then, $8 \mathrm{~mL}$ of $12 \mathrm{M}$ sulfuric acid was added. The flasks were covered with a glass lid and left for 2 hours. Then, 184 
$\mathrm{mL}$ of distilled water was added to dilute the $12 \mathrm{M}$ sulfuric acid to $0.5 \mathrm{M}$ (56). The soil samples were placed in an oven at $85^{\circ} \mathrm{C}$ for 16 hours to hydrolyze soil polysaccharides (55). The samples were centrifuged at $5000 \mathrm{rpm}$ for 15 minutes and supernatants were filtered through Whatman filter papers grade 595 (22). To quantify polysaccharides, $5 \%$ phenol reagent was added $(56,57)$. Glucose standards $(0.5 \mathrm{mg} / \mathrm{L}, 1 \mathrm{mg} / \mathrm{L}, 1.5 \mathrm{mg} / \mathrm{L})$ were prepared and their absorbance were measured at $490 \mathrm{~nm}$ with a UV/VIS spectrophotometer (Jenway) $(56,58)$.

To determine the chemical degradability of polysaccharides, $3 \mathrm{~g}$ of each soil samples was sieved by standard mesh No. 140 (particle size less than $0.1 \mathrm{~mm}$ ) and spread on the surface of a Petri dish and placed under a UV-B lamp (T5 8W, 220-240 V) with maximum radiation at a wavelength of $254 \mathrm{~nm}$. Triplicates of each soil sample were prepared. The first, second, and third series were exposed to UV radiation for 24,48 , and 72 hours, respectively. Then, based on the above-mentioned method, the polysaccharides content in the soil was measured in each sample.

\section{High-Performance Liquid Chromatography (HPLC)}

To identify monosaccharides from the chemically hydrolyzed soil polysaccharides, the HPLC method was applied using a PUMP K-1001 (KNAUER GmbH, Berlin, Germany), Nucleosil-100 NH2 column $(250 \times 4.6 \mathrm{~mm}$, $5 \mu \mathrm{m}$ ), and a K-2301 Refractive Index (RI) detector. The mobile phase and flow rates were acetonitrile/water (80:20 $\mathrm{v} / \mathrm{v}$ ) and $1 \mathrm{~mL} / \mathrm{min}$, respectively. $20 \mu \mathrm{L}$ of the sample was injected onto the column at $30^{\circ} \mathrm{C}$ and four types of monosaccharides including glucose, mannose, xylose, and arabinose were examined in the 20 soil samples.

\section{Statistical analyses}

Pearson's correlation coefficient was calculated to investigate the linear relationship between two variables (59), i.e. soil physicochemical parameters under biocrust coverage and non-biocrusted samples. Then, principal component analysis (PCA) statistical test (60) was used to analyze the effect of soil properties on biocrust formation.

\section{Results}

Specifications of lichen species identified in Sejzi desert A total of 32 species of terrestrial lichens were collected from Sejzi desert. Most of the lichens were classified as cyanolichens, i.e. their photobiont partners are represented by cyanobacterial species. Images of the most frequent cyanolichens in Sejzi plain are shown in Figure 3.

\section{The relationship between soil properties and biocrust distribution}

Soils underneath biocrusts showed a significant Pearson's correlation with soil stability indexes (Table 1). The samples had the highest correlation with the MWD, dry soil stability index (ADS), OC (\%), and N (\%). Based on the data in Table 1, biocrust increased the MWD, thereby, reducing the erosion rate. Due to decreasing amount of particles with a size less than $0.84 \mathrm{~mm}(\mathrm{~d}<0.84 \mathrm{~mm})$, the present biocrusts reduced soil erosion in Sejzi plain, as reflected in an inverse relationship between this parameter and biocrusts.

The ADS index data showed that the occurrence of biocrust $(r=-0.657)$ is effective on soil strength, i.e. by increasing the aggregation of soil particles in the dry state due to the collision with other particles at a high speed. This shows what percentage of the average amount of silt has changed to clay. The negative correlation between the soil underneath the biocrusts and the ADS index indicates the positive effect of the biocrust cover on increasing the aggregate resistance. According to Eq. 2, with increasing biocrust cover, the ADS index will be reduced. According to the relationship between WAS (0.623) index and MWD (0.702), biocrusts also increased soil stability in wet situation, so they protect soil against water erosion. Based on the EC measurements in the soil samples of Sejzi Desert, it can be concluded that the salinity of soils negatively affects the biocrust distribution. Biocrusts led to an increase in the percentage of OC and N, thereby, improving the soil quality. The soil samples underneath the biocrusts collected from lichen-dominated areas, showed a positive correlation with the percentage of clay. In comparison with silt or sandy soils, clay has an important role to be rather stable in the field, so lichens are preferentially found in clay soils. In Sejzi desert, biocrusts do not have a significant effect on increasing $\mathrm{CaCO}_{3}$ (\%) in the soil. Although this relationship is not significant at $95 \%$ level, there is a positive relationship between the percentage of lime and biocrusts. $\mathrm{pH}$ had a low significant effect on the distribution of biocrusts at $95 \%$ confidence level. The percentage of OC and $\mathrm{N}$ showed a strong negative significant correlation with ADS index.

PCA was performed to classify all factors influencing a biocrusted and non-biocrusted soil based on the correlation between the parameters (Figure 4a). The score plot shows that all parameters affected by biocrusts (red points that were classified as number 1) separated from the other parameters (black points that were classified as number 0 ).

The loading plot was performed based on the highest covariance difference of soil parameters (Figure 4b). This plot clearly shows that the covariance difference of OC (\%), $\mathrm{N}(\%), \mathrm{ADS}, \mathrm{MWD}, \mathrm{WAS}, \mathrm{CaCo}_{3}(\%)$, and $\mathrm{pH}$ parameters in biocrusted soil are low, and hence, these parameters are the most important factors. Conversely, the lowest differences of covariance were observed in the EC, $\mathrm{d}<0.84 \mathrm{~mm}$, silt (\%) and sand (\%) values in nonbiocrusted soils. Moreover, loading of PCA, indicated that the maximum length of the axis belonged to OC (\%), $\mathrm{N}$ (\%), MWD, WAS, and ADS, so in these parameters, the 

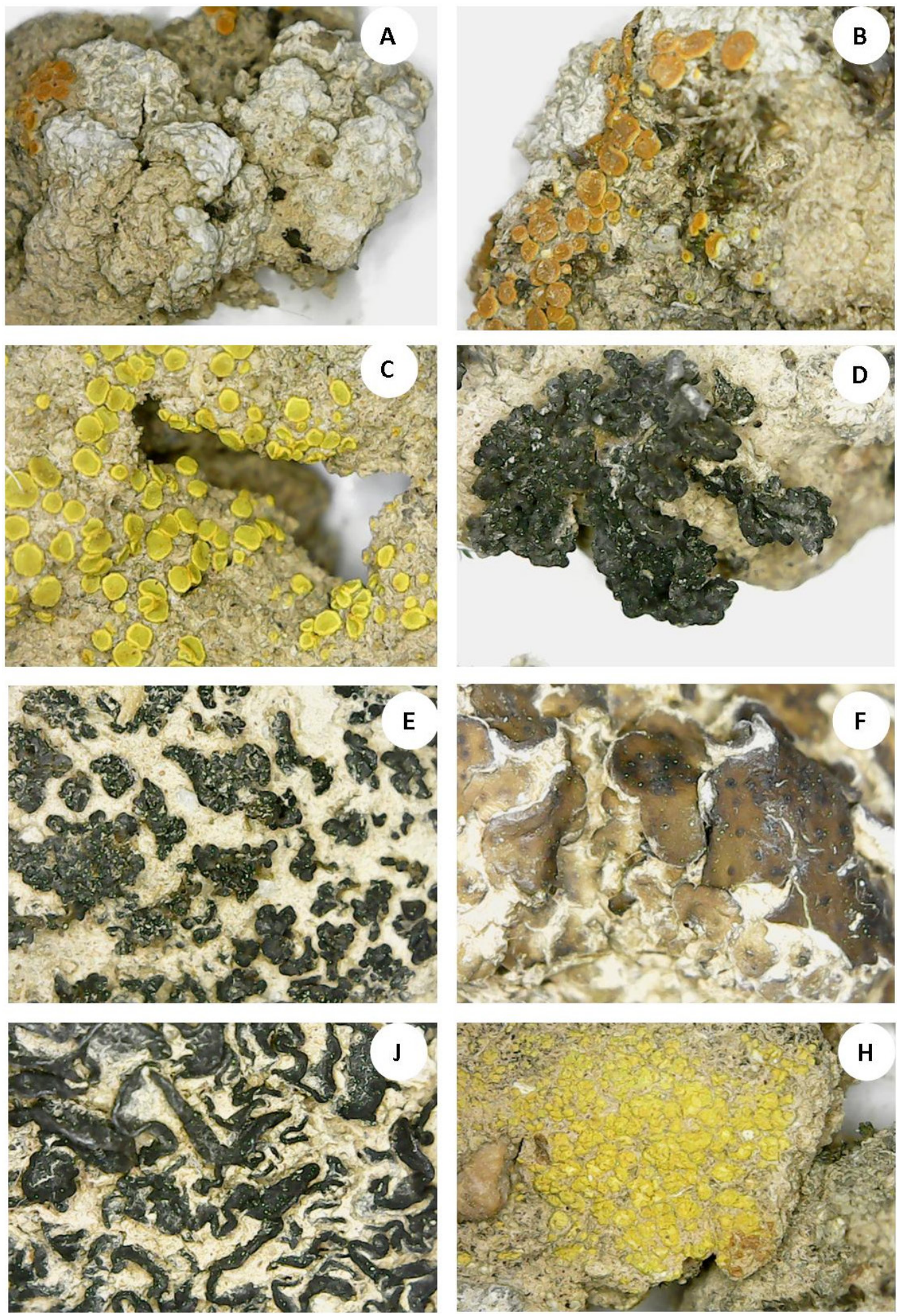

Figure 3. Some species of terrestrial lichens in Sejzi desert. A: Circinaria mansourii,

B: Caloplaca borysthenica raesaenenii, C: Candelariella sp, D: Enchylium tenax, E: Peccania terricola, F: Placidium squamulosum, J: Blennothallia crispa, $\mathrm{H}$ : Xanthocarpia tominii.

difference in the covariance of the biocrust community samples is minimal.

Analysis of PC1 component, which compared soil parameters at level $67.6 \%$, showed the highest covariance difference among soil samples, which was related to soil texture and EC. The non-biocrusted soil samples contained more sand and silt than biocrusted soil samples, whereas biocrusted soil samples had higher clay content. The higher values of $\mathrm{CaCO}_{3}$ were measured in the biocrusted soil samples. The second component of PC2 at level 21.8\% indicated that the differences in covariance are related to sand (\%), silt (\%), clay (\%), $\mathrm{CaCO}_{3}(\%), \mathrm{d}<0.84 \mathrm{~mm}$, and 


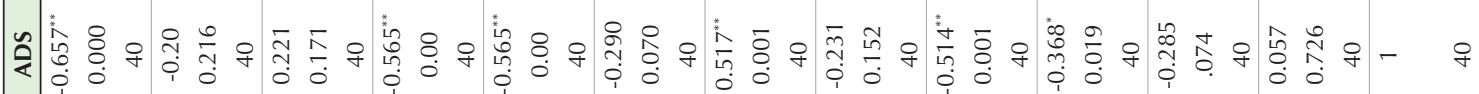

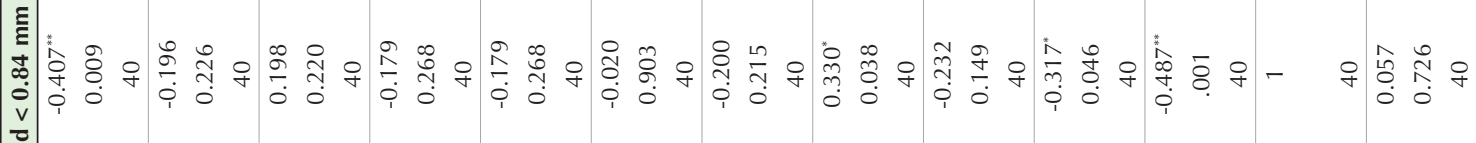

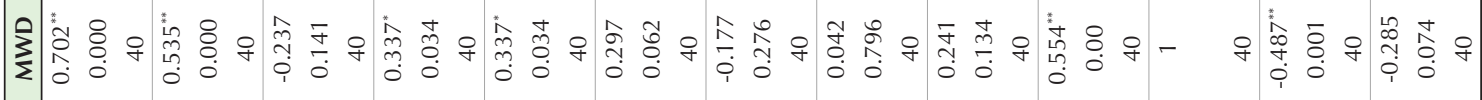

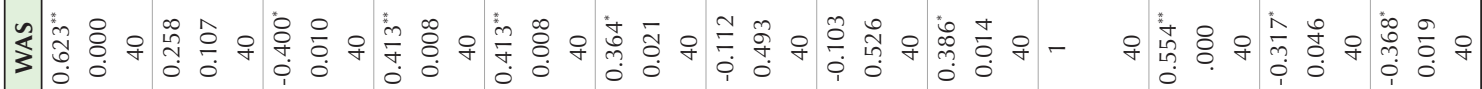
元

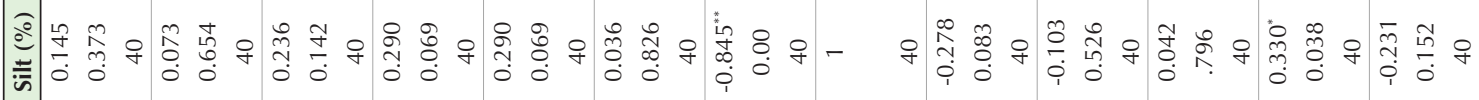

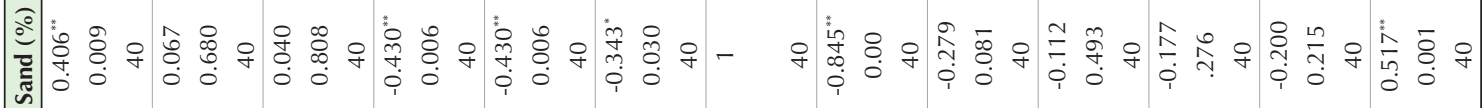

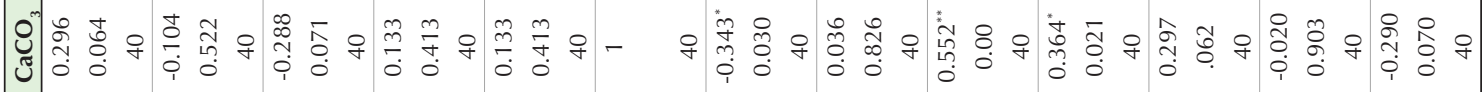
Z

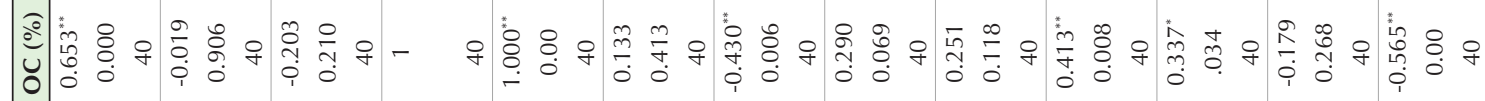

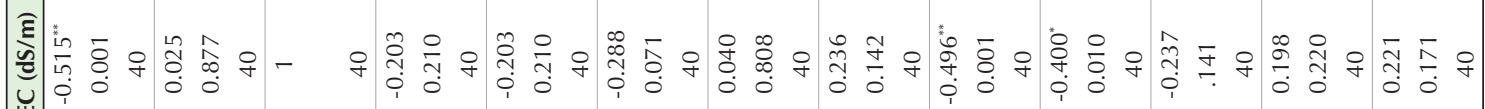

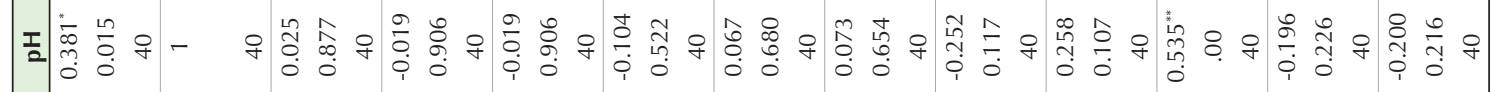

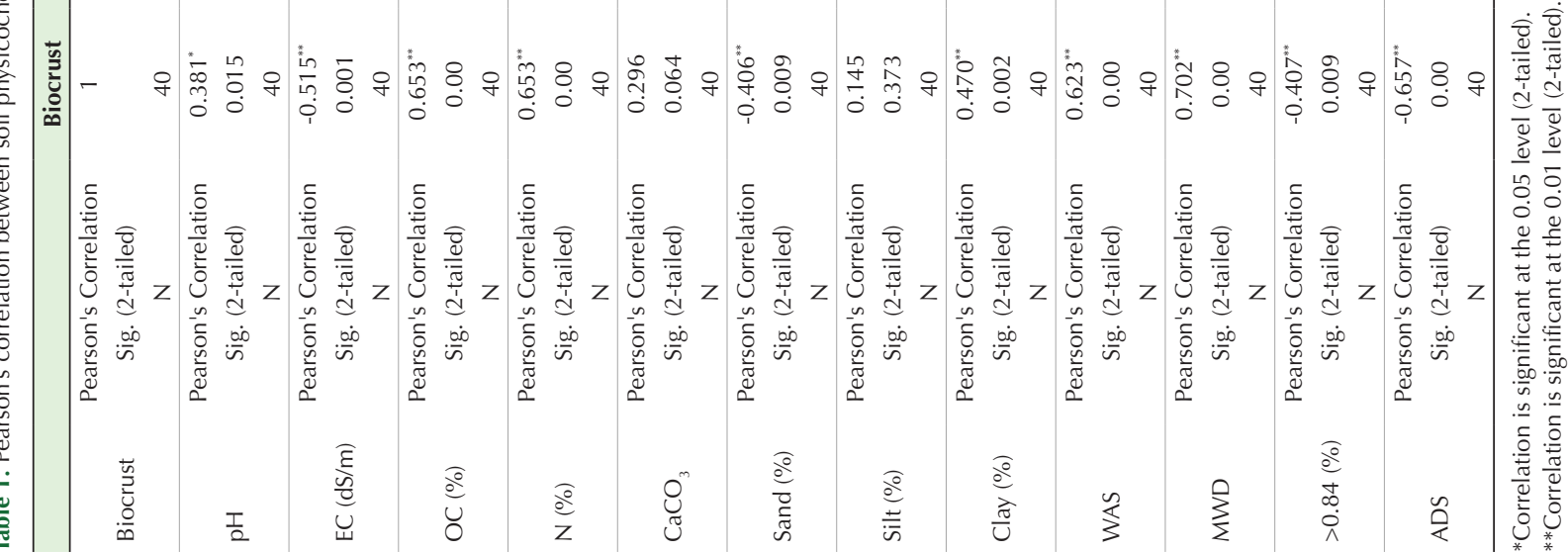




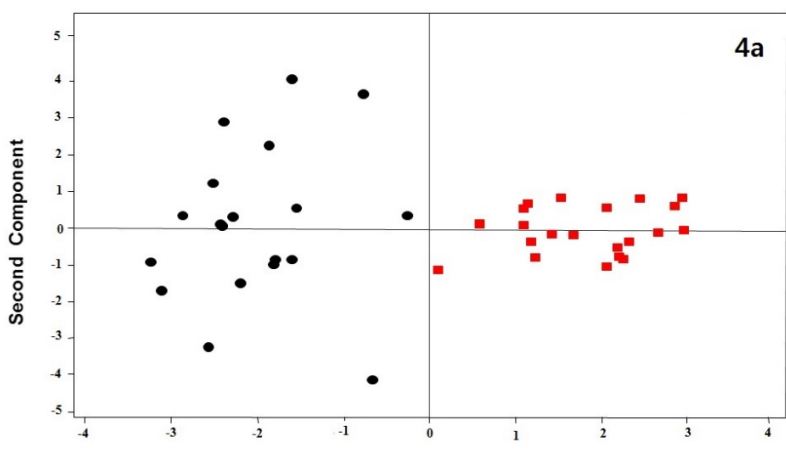

- Without biocrust cover

- Soil under biocrust cover First Component

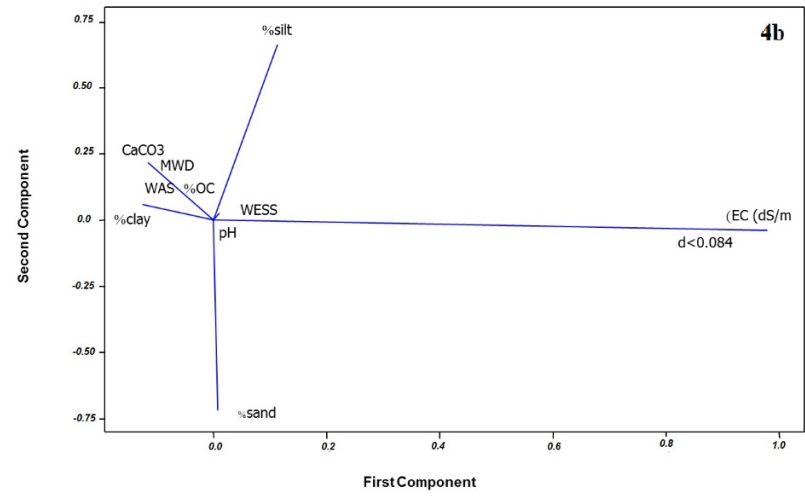

Figure 4. (a) PCA ordination density plot of the first and second components of biocrust and (b) variables and individuals factor maps in principal component analysis.

EC of the soil samples (Figures $5 \mathrm{a}$ and $\mathrm{b}$ ).

\section{Soil organic compounds identification via FTIR}

Chemical components of soils with an OC (\%) more than $0.5 \%$, were analyzed by the FTIR spectra (Table 2 ). Some of the samples exhibited a stronger intensity of absorption than the others, as shown, for example, for sample 567 (Figure 6).

\section{EPS content of biocrusted soil samples}

The polysaccharide contents among the soil samples were different. The highest amount of polysaccharide was $0.16 \%$, which belonged to sample 581 and the lowest one was $0.05 \%$ as determined in samples 564, 565, and 572. After being placed under UV-B radiation, the amounts of polysaccharide were measured again in the previous soil samples, which indicted the highest content of polysaccharides by $0.11 \%$ and $0.10 \%$ in the samples 574, 575, and 567, respectively. There was no statistically significant difference between the amount of polysaccharides of UV-B-treated soil samples at both 48 and 72 hours (t-test). There was a difference in the amount of EPS between control samples and soils exposed to UV-B for $24 \mathrm{~h}(\mathrm{t}$-stat $=2.97$, $\mathrm{t}$-critical $=1.96)$ and 48 hours $(\mathrm{t}$-stat $=2.15, \mathrm{t}$-critical $=1.69)$. Therefore, UV-B degraded the polysaccharides by $50 \%$ in the soil samples during $48 \mathrm{~h}$ of exposure to UV-B (Figure 7). The amount of EPS in the sample 567 was similar to the other samples (Table 3), but EPS or the biocrust species were more resistant to UV-B compared to the other samples. The same results could be seen in the samples 574 and 575 (Table 3).

Biocrust species in these samples included as cyanolichen dominated Peccania terricola, Collema tenax, Collema cocophorum, and Placidium squamulosum. But these species also observed in other samples (Figure 7).

EPS\% was also measured along with a vertical soil depth profile in 3 selected samples (Table 3 ), and the polysaccharide values increased in the soil depth. In all samples, EPS\% was enriched at a soil depth of $15-25 \mathrm{~cm}$

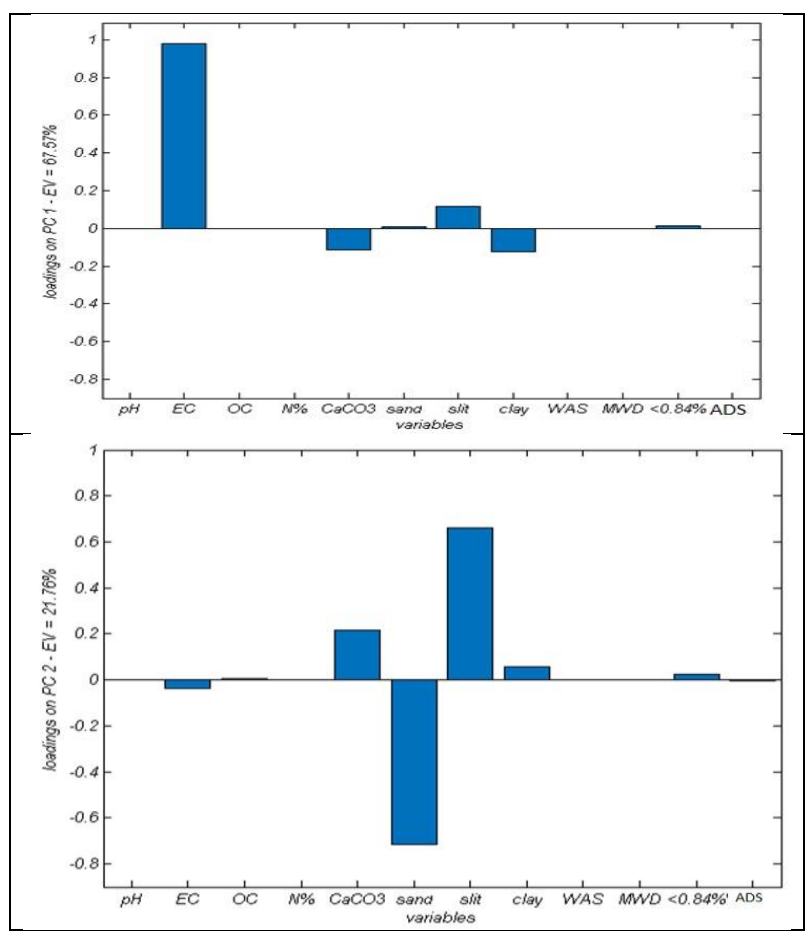

Figure 5. Pairwise regression between PCA1 (a) and PCA2 (b) scores and mean amount of soil parameters under biocrust and soil without biocrust cover across the 20 sampling sites.

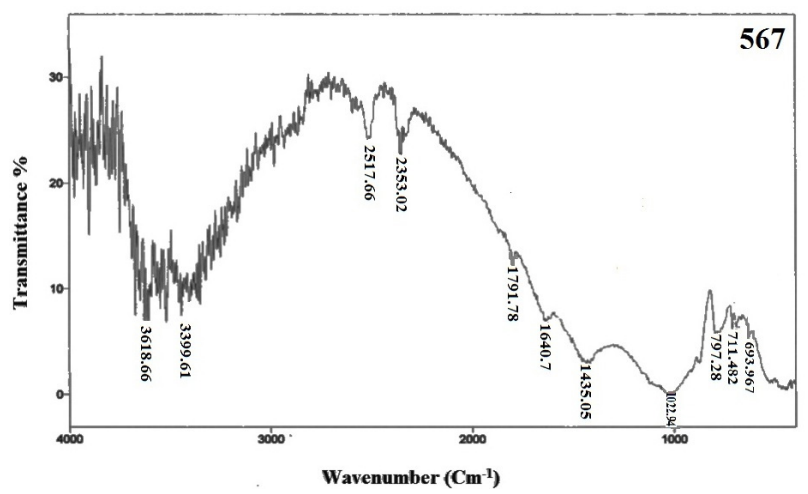

Figure 6. Diffuse reflectance infrared Fourier transform (DRIFT) spectra of a soil sample across a range of $\mathrm{KBr}$ dilution of $2.0 \mathrm{mg}$ sample/200 mg. 
Table 2. FTIR vibrational assignments for soil organic and inorganic matter absorbance - Biocrusted soil sample No. 567

\begin{tabular}{|c|c|c|c|}
\hline Wavenumbers $\left(\mathrm{cm}^{-1}\right)$ & Organic Assignment & Organic Matters & Inorganic (matrix) Constituent \\
\hline 693.967 & - & - & $\mathrm{SiO}_{2} \mathrm{Si}-\mathrm{O}-\mathrm{Si}$ bending', Iron oxides', lattice \\
\hline 711.482 & $\begin{array}{l}\text { Aromatic } \mathrm{C}-\mathrm{H} \text { out-of-plane bend; } \\
\text { increasing wavenumbers with } \\
\text { increasing degree of substitution }\end{array}$ & $\begin{array}{l}\text { Soila, soil organic horizons }{ }^{\mathrm{a}} \text {, humic acids } \\
\text { of soil }^{\mathrm{b}, \mathrm{c}}\end{array}$ & Water' \\
\hline 797.28 & $\begin{array}{l}\text { Aromatic } \mathrm{C}-\mathrm{H} \text { out-of-plane bend; } \\
\text { increasing wavenumbers with } \\
\text { increasing degree of substitution }\end{array}$ & $\begin{array}{l}\text { Soila }{ }^{\mathrm{a}} \text {, soil organic horizons }{ }^{\mathrm{a}} \text {, humic acids } \\
\text { of soil }^{\mathrm{b}, \mathrm{c}}\end{array}$ & $\begin{array}{l}\mathrm{C}-\mathrm{H} \text { bending (non-aromatic) }-\mathrm{SiO}_{2} \text { lattice } \\
\text { stretching }^{\mathrm{n}} \mathrm{SiO}_{2} \text { silicate }^{\mathrm{n}}\end{array}$ \\
\hline 1022.94 & $\begin{array}{l}\text { Ester, phenol } \mathrm{C}-\mathrm{O}-\mathrm{C}, \mathrm{C}-\mathrm{OH} \text { stretch, } \\
\text { attributed to polysaccharides }\end{array}$ & $\begin{array}{l}\text { Humic acids of soild, soil organic } \\
\text { horizons }^{\mathrm{e}}\end{array}$ & Silicate Si-O stretching (kaolinite, illite) ${ }^{1}$ \\
\hline 1435.05 & Aliphatic $\mathrm{C}-\mathrm{H}$ bend & Humic acids of soil ${ }^{b, c}$ & $\begin{array}{l}\mathrm{C}-\mathrm{O} \text { stretching }{ }^{\mathrm{l}}, \mathrm{Mg}-\mathrm{OH} \text { stretching } \\
\text { montmorillonite }\end{array}$ \\
\hline 1640.7 & Amide $\mathrm{C}=\mathrm{O}$ stretch (amide $\mathrm{I}$ ) & Humic acids of soil ${ }^{b, c}$ & amide $\mathrm{I}$, aromatic $-\mathrm{C}=\mathrm{C}-$ stretching ${ }^{\mathrm{f}}$, water \\
\hline 1791.76 & Carbonyl $\mathrm{C}=\mathrm{O}$ stretch & $\begin{array}{l}\text { Humic acids of soil }{ }^{\mathrm{b} h \mathrm{~h}, \mathrm{~d}} \text { and water } \\
\text { extractable OM of soilg8 }\end{array}$ & $\mathrm{C}=\mathrm{O}$ stretching ${ }^{\prime}, \mathrm{SiO}_{2}{ }^{\prime}$ \\
\hline 2353.02 & & & $\mathrm{SiO}_{2}{ }^{1}$ \\
\hline 2517.15 & $\mathrm{H}$-bonded $\mathrm{OH}$ of carboxylic acids & Humic acids of soil ${ }^{b, c}$ & $\mathrm{SiO}_{2}{ }^{1}$ \\
\hline 3399.51 & $\begin{array}{l}\text { Hydrogen bonded } \mathrm{O}-\mathrm{H}, \mathrm{N}-\mathrm{H} \text { stretch; } \\
\text { greater } \mathrm{N}-\mathrm{H} \text { contribution at lower range }\end{array}$ & $\begin{array}{l}\text { Humic acids of soil } l^{h, c, k} \text { and pyrophosphate } \\
\text { extracts of soil }{ }^{b} \text {, }\end{array}$ & $\begin{array}{l}\mathrm{O}-\mathrm{H}^{\mathrm{b}}, \mathrm{H}-\mathrm{O}-\mathrm{H}^{\mathrm{r}}, \text { Water } \\
\text { and } \text {, Carboxyl, alcohols } \\
\text { phenols/amine and amide }{ }^{\mathrm{m}}\end{array}$ \\
\hline 3618.65 & Free $\mathrm{O}-\mathrm{H}, \mathrm{N}-\mathrm{H}$ stretch & Humic acids ${ }^{c, b}$ and fulvic acids of soil ${ }^{b}$ & $\mathrm{Al}(\mathrm{Mg}) \mathrm{Si}-\mathrm{OH}$ stretchingl \\
\hline
\end{tabular}

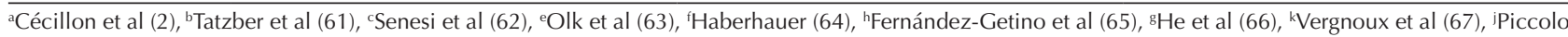

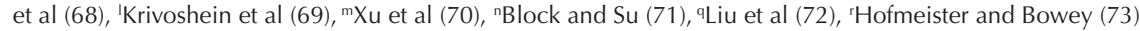

Table 3. EPS (\%) in three depths of soil in three soil samples

\begin{tabular}{lccc}
\hline Depth of Soil $(\mathbf{c m})$ & EPS (\%)-567 & EPS (\%)-574 & EPS (\%)-575 \\
\hline $0-10$ & 0.12 & 0.13 & 0.12 \\
\hline $10-15$ & 0.136 & 0.16 & 0.13 \\
\hline $15-25$ & 0.138 & 0.194 & 0.139 \\
\hline
\end{tabular}

in comparison with the soil depth of $10-15$ and $0-10 \mathrm{~cm}$ (Table 4).

\section{High-Performance Liquid Chromatography}

Mannose, glucose, arabinose, and xylose were detected as the monosaccharide composition of EPS in the underneath biocrusts soil samples (Table 4). Arabinose was present at all soil samples, while none of the abovementioned monosaccharides could be seen in two samples, 565 and 566, which were collected from the soil underneath of Peccania arizonica and moss, respectively, could be detected. The soil samples collected from the underneath of Collema tenax and Collema coccophorum contained different amounts of arabinose. Xylose was detected in sample 571 .

\section{Discussion}

The most effective role of biocrusts to improve soil properties

Soil samples were collected according to the Sejzi plain rainfall regime in early December at the same time as the peak of biocrust activity occurred, during a season that the number of sunny days and sunny hours were low. Because of general life strategies of biocrust species during the environmental stress, such as low availability of soil water

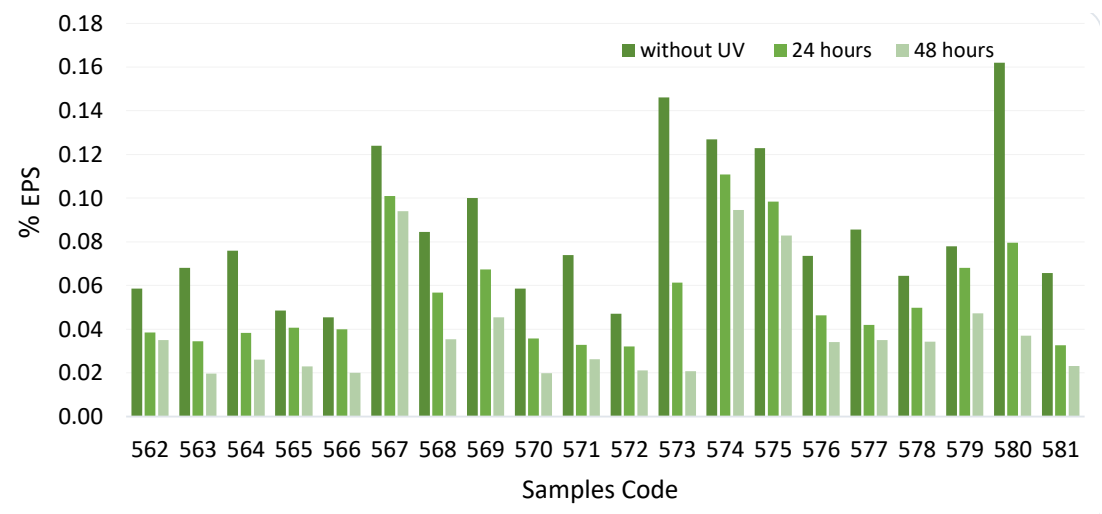

Figure 7. The percentage of EPS (\%) affected by the UV-B after 24 and 48 hours of treatment. 
Table 4. Biocrust and monosaccharides of the soil samples.

\begin{tabular}{|c|c|c|c|c|c|}
\hline No. & Code & X LL & YLL & Lichen & Monosaccharides \\
\hline 1 & 562 & 522019 & 325418.50 & Moss, Algae & Xylose, Arabinose \\
\hline 2 & 563 & 52943.10 & 32555.80 & Moss, Algae, Collema coccophorum & Xylose, Mannose \\
\hline 3 & 564 & 52183.80 & 325342.40 & Moss, Algae, Collema coccophorum & Xylose, Mannose \\
\hline 4 & 565 & 52943.60 & 32555.40 & Peccania arizonica & - \\
\hline 5 & 566 & 521853.10 & 325344.80 & Moss & - \\
\hline 6 & 567 & 52.1915 .30 & 325231.80 & Moss, Collema coccophorum & Arabinose \\
\hline 7 & 568 & 522019.70 & 325417.90 & Moss & Xylose \\
\hline 8 & 569 & 52118.30 & 32558.70 & Collema tenax, Moss & Arabinose \\
\hline 9 & 570 & 521853.70 & 325342.20 & Collema tenax, Endocarpon pusillum, Candelariella sp, Moss & Arabinose, Mannose \\
\hline 10 & 571 & 521641.90 & 325451.80 & $\begin{array}{l}\text { Candelariella sp, Caloplaca borysthenica, Megaspora rimisorediata, } \\
\text { Caloplaca raesaenenii, Moss }\end{array}$ & Xylose \\
\hline 11 & 572 & 52943.10 & 32555.90 & Endocarpon pusillum & Arabinose, Mannose \\
\hline 12 & 573 & 52118.50 & 32558.10 & $\begin{array}{l}\text { Collema coccophorum, Circinaria mansourii, Placidium squamulosum, } \\
\text { Moss }\end{array}$ & Arabinose, Mannose \\
\hline 13 & 574 & 521914.60 & 325229.10 & Collema tenax, Collema coccophorum, Placidium squamulosum & Arabinose, Mannose \\
\hline 14 & 575 & 521643.30 & 325451.80 & Peccania terricola, Collema tenax, Collema coccophorum & Xylose, Arabinose, Mannose \\
\hline 15 & 576 & 521947.80 & 32544.60 & Moss, Collema coccophorum & Arabinose, Xylose, Mannose, Glucose \\
\hline 16 & 577 & 522019 & 325418.40 & Moss, Collema coccophorum & Arabinose \\
\hline 17 & 578 & 521947.50 & 32545.20 & Moss, Collema coccophorum, Collema tenax & Arabinose \\
\hline 18 & 579 & 52194.40 & 32545.10 & Collema coccophorum, Peccania terricola & Arabinose \\
\hline 19 & 580 & 521853.50 & 325342.10 & Candelariella sp & Arabinose \\
\hline 20 & 581 & 521642.20 & 325451.70 & Circinaria mansourii, Circinaria elmorei, Collema tenax, Candelariella sp & Arabinose \\
\hline
\end{tabular}

or enhanced UV radiation in summer, their metabolic activities temporarily stop until the abiotic conditions improve. Biocrusts play important ecological roles in improving soil properties in different ways (74), such as increasing OC (\%) $(75,76)$ and $\mathrm{N}(\%)$ (77), producing $\mathrm{CaCO}_{3}$ and EPS, which increase soil stability and aggregate formation (78), gluing soil particles together, thereby, making large aggregates by biocrust filaments (79), adjusting the effect of anions and cations such as reduction of soil EC and exchangeable sodium (80), and rising soil porosity and infiltration (81). According to the data belonged to ADS, WAS, and WMD, biocrusts could enhance soil OC and so improve soil quality and stability. Therefore, it can be possible to use biocrusts to increase the carbon sequestration process, to modify the quality of Sejzi desert soil, and finally, to control wind erosion. This ecological strategy will provide a useful solution to combat desertification.

Some reports consider particle size less than $0.84 \mathrm{~mm}$ as an index of wind erosion for the top soil (82); reducing the diameter of dry clay to $0.1 \mathrm{~mm}$ is effective against wind erosion. If the diameter of the dry particles in the soil is less than $0.1 \mathrm{~mm}$, the wind erosion will be reduced. This is because a unit volume of the smallest aggregates has the greatest surface for protecting the erodible particles (82) and the fluid and impact threshold drag velocities for dry grains greater than $0.1 \mathrm{~mm}$ in diameter vary as the square root of the product of equivalent diameter of the grain and the density relationship of the fluid and the grain (83). The threshold drag velocity for a mixture of different comparable sizes of erodible particles is less than that required to erode only the largest particles. Movement of the larger particles is facilitated by bombardment received from the smaller particles moving in saltation (83). It is clear that the ADS index indicates that the presence of biocrusts $(r=-0.657)$ is effective in increasing soil strength. The ADS index shows the extent to which greater aggregates are broken down when bombarded by other particles. Based on the results of the present study, biocrusts using their filaments and secreting exopolysaccharides in the soil content, had made greater aggregates, which have more cohesion and adhesion. It means that these aggregates are broken less than the other particles in soil content without biocrust cover. Therefore, strengthening the community of biocrusts is an effective idea to reduce dust storms. As a result of the wind blowing, the aggregates separate from their beds and first creep. By increasing wind velocity, lighter particles move near the earth's surface by saltation in the air. These aggregates are separated from their substrates and are affected by the force of the wind friction. Besides, they collide with other particles in the air and disintegrate. If this process frequently occurs in the field, the soil aggregates are constantly broken and become smaller and lighter, and as a result, will be more easily removed from the bed even by medium and low wind speed, which will enhance 
their distribution in the air, causing dust storms. But, soil limiting factors for biocrust cover in Sejzi desert are EC, soil texture, and $\mathrm{CaCO}_{3}(\%)$, respectively. To combat desertification in Sejzi desert, these soil parameters must always be considered first, especially the limitation by EC and soil texture, and according to these results, rehabilitation measures can be adopted and applied. Such measures include the utilization of biocrust organisms, such as suitable lichens or microorganisms, to improve soil conditions, for example, by reducing erosion processes, thereby, combating desertification. To identify suitable biocrust microorganisms, they have first to be isolated from field samples, purified and established as clonal cultures. Afterwards, they can be characterized in terms of their stress tolerance and productivity, and promising strains can be used for field application, for example, by spraying on degraded soils, thereby, promoting artificial biocrust formation (84).

\section{Selecting a perfect soil sample to isolate suitable biocrust species}

The carbohydrates constitute between $5 \%$ and $25 \%$ of the soil organic matter (85). The presence of a substantial polysaccharide fraction in a relatively stable form in the soil humus indicates that: (a): It consists of polysaccharides of microbial and plant origin which are resistant to decomposition. (b): That certain plant or microbial polysaccharides or their partial degradation products form salts or complexes with metal ions, clays, or humic complexes which are resistant to decomposition. (c): That new complex polysaccharide molecules characteristics of or peculiar to the soil environment are formed which are resistant to decomposition, or that (d): A combination of all or some of the above-mentioned factors are involved (86). All these components were found in soil samples content according to their FTIR spectra. The peaks at 1000 to $1030 \mathrm{~cm}^{-1}$, which were related to $\mathrm{C}-\mathrm{H}$ bands, were identified as polysaccharides from FTIR spectra. The Si-O stretching vibrations of kaolinite and dickite give several well-resolved strong bands in the 1120-1000 $\mathrm{cm}^{-1}$ region. The di- or trioctahedral nature of a mineral apparently influences where the $\mathrm{Si}-\mathrm{O}$ stretching band appears within a spectrum, as bands for the trioctahedral minerals which appear at higher wavenumbers (1030$\left.1020 \mathrm{~cm}^{-1}\right)$ than the dioctahedral minerals $(\sim 1010$ $\mathrm{cm}^{-1}$ ) (86). Mineral absorbance corresponds to that of the constituent units. The $3750-3400 \mathrm{~cm}^{-1}$ region corresponded to $\mathrm{OH}$ stretching vibrations. In the 950-600 $\mathrm{cm}^{-1}$ region, $\mathrm{OH}$ bending vibrations occur. Absorption of $\mathrm{Si}-\mathrm{O}$ stretching vibrations is a characteristic for the 1200 $700 \mathrm{~cm}^{-1}$ region and absorption band of $\mathrm{Si}-\mathrm{O}$ bending vibrations is between 600 and $150 \mathrm{~cm}^{-1}(87)$. Several new vibration bands appeared at $\sim 3399,1640$, and $1435 \mathrm{~cm}^{-1}$ in the FTIR spectra of $\mathrm{NH}_{3}$-adsorbed montmorillonite samples (Figure 5) and were attributed to the coordinated
$\mathrm{NH}_{3}$ to the Lewis acid sites (denoted as $\mathrm{L}: \mathrm{NH}_{3}, \sim 3399$ and $\left.1640 \mathrm{~cm}^{-1}\right)$ and $\mathrm{NH}_{4}\left(1435 \mathrm{~cm}^{-1}\right)$ (87-89). The broad band spanning (3500-3200 $\mathrm{cm}^{-1}$ ) was assigned to $\mathrm{O}-\mathrm{H}$ vibration from water, alcohols, carboxylic acids, phenols, and $\mathrm{N}-\mathrm{H}$ vibration for amides $(88,89)$. The peak at 3620 $\mathrm{cm}^{-1}$ originated from the stretching vibration of $\mathrm{O}-\mathrm{H}$ in the clay minerals (90). In the case of overlaps between $\mathrm{C}=\mathrm{N}$ (amide II) and aromatic $\mathrm{C}=\mathrm{C}$ at $1530 \mathrm{~cm}^{-1}$, or polysaccharide type (e.g. lignin, cellulose, and pectin) for C-O absorbance at $1160-1020 \mathrm{~cm}^{-1}$ (91).

The high values of polysaccharides in soil can not the only reason for the suitability of aggregates. The biocrust species had possibly produced a large amount of EPS, which is degradable under environmental stresses such as UV-B. Thus, the biocrusts which produce more EPS are not always the most suitable organisms. In addition, the EPS resistance against UV-B is not sufficient to use them in arid regions to improve soil quality. As mentioned before, under drought conditions, high UV-B and salinity, biocrusts use different mechanisms to adapt and settle in the field, and they stop their biological activities which prevent formation of soil aggregates. So, both resistance and the EPS (\%) are important before the biocrusts start their activities again and produce useful compounds in soil content. All samples collected from soils containing biocrust had different amounts of polysaccharide with high amounts in three samples of 567,574 , and 575, which showed the highest resistance to UV-B. Therefore, the native biocrust species in these three samples might be suitable to combat desertification in arid and semi-arid regions. However, the underlying organisms that had the most effectiveness to EPS production, have not yet been identified. Identification of super molecules of polysaccharides that are secreted in soil content by microorganisms, is very difficult. It is clear that the monosaccharides never have a role in soil functions as those secreted by biocruts. However, the role of monomer of polysaccharides identification can be evaluated based on some of soil physicochemical properties such as increasing of aggregates stabilization. However, it depends on the clay type in soil, because all clay anions and cations have strong interactions with EPS and formation of aggregates in soil content. For example, $\mathrm{K}$ of kaolinite and $\mathrm{Ca}$ and $\mathrm{Mg}$ of montmorillonite play a main role in establishing chemical bonds in soil content. So, it is necessary to determine the type of clay in soil content. Therefore, identification of monosaccharides, which play a main role in increasing soil stability, is so difficult and it is necessary to investigate all the functions between soil structure and monosaccharides. They must be tested in many types of soil, in terms of soil texture, types of clay, bulk density, particle density, $\mathrm{EC}, \mathrm{CaCo}_{3}$, soil water content, and etc. to understand the main reason of EPS resistance in these three soil samples. It is difficult to determine which monomer plays the most important 
role in functions between clay mineral's cations or anions. Maybe just the supermolecule of EPS plays the main role and it is wrong to test each of monomers to understand the soil functions in this way.

Finally, from an applied perspective, it is important to exactly determine which species has the greatest potential for settlement in Sejzi desert and are suitable to combat desertification. The macro biocrust species in these three samples are dominated by the cyanolichen Collema coccophorum, Collema tenax, Peccania terricola, and Placidium squamulosum, which had the highest amounts of EPS (\%) (Figure 3). In these samples, the symbiotic microorganisms may play an important role in producing EPS. Therefore, the main species of biocrusts, which are photoautotrophic and can be located in Sejzi desert, are the photobiont part of cyanolichens, namely some species of cyanobacteria. In deserts, terrestrial biocrust communities are the main species to investigate their effects in soil properties. Therefore, it could be assumed that in the same condition of cultures, the cyanobacteria that are symbiosis with cynolichens, have more adaptation to their environment, as a result of which, they have gained more resistance to harsh environmental conditions. Maybe it is related to their succession processes in nature. Lichen-dominated areas appears one or two stages after moss-dominated areas and they have gone through more difficult stages and settled in their habitat, so they can be survived under UV-B more than the other specimens that had been symbiosis with mosses.

\section{Conclusion}

However, there are still many open questions which must be addressed in follow-up studies of this less-well investigated region. The relationship between biocrusts and wind or water erosion indices must be determined in our country, Iran. It is very important to investigate biocrust affection in aggregates stability, soil limiting factors to settlement of biocrusts. Finding suitable biocrust organisms as soil engineers is of great importance for the arid regions of Iran as a natural strategy to reduce soil erosion.

\section{Acknowledgements}

The authors would like to express their gratitude to Department of Watershed Management of Isfahan Agriculture and Natural Resources Research Center, for cooperation in sampling in Sejzi desert.

\section{Ethical issues}

The authors hereby certify that all data collected during the research are as expressed in the article, and no data from the study has been or will be published elsewhere separately.

Competing interests

The authors declare that they have no conflict of interests.
Authors' contributions

All authors were involved in the research design, experiments, data analysis, and article writing. The final version of the article was reviewed and confirmed by all of them.

\section{References}

1. Miralles I, Lazaro R, Sanchez-Maranon M, Soriano M, Ortega R. Biocrust cover and successional stages influence soil bacterial compositionand diversity in semi arid ecosystems. Science of the Total Environment 2020; 709: 134654. 1-48. doi: 10.1016/j.scitotenv.2019.134654.

2. Cécillon L, Certini G, Lange H, Forte C, Strand LT. Spectral fingerprinting of soil organic matter composition. Geophysical Research Abstracts 2009; 11: EGU2009-7202.

3. Wang F, Michalski G, Luo H, Cafee M. Role of biological soil crusts in affecting soil evolution and salt geochemistry in hyper-arid Atacama Desert, Chile. Geoderma 2017; 307: 54-64. doi: 10.1016/j.geoderma.2017.07.035.

4. Kidron GJ. Differential water distribution over dune slopes as affected by slope position and microbiotic crust, Negev Desert, Israel. Hydrological Processes 1999; 13(16): 1665-82. doi: 10.1002/(SICI)1099-1085(19990815)13:11<1665::AIDHYP836>3.0.CO;2-R.

5. Mazor G, Kidron GJ, Vonshak A, Abeliovich A. The role of cyanobacterial exopolysaccharides in structuring desert microbial crusts. FEMS Microbiology Ecology 1996; 21(2): 121-30. doi: 10.1016/0168-6496(96)00050-5.

6. Tisdall JM, Nelson SE, Wilkinson KG, Smith SE, McKenzie BM. Stabilization of soil against wind erosion by six saprotrophic fungi. Soil Biology and Biochemistry 2012; 50: 134-41. doi: 10.1016/j.soilbio.2012.02.035.

7. Carbonero ER, Montai AV, Woranovicz-Barreira SM, Gorin PA, Iacomini M. Polysaccharides of lichenized fungi of three Cladina spp.: significance as chemotypes. Phytochemistry 2002; 61(6): 681-6. doi: 10.1016/s00319422(02)00363-1.

8. Kirdon GJ, Ying W, Starinsky A, Herzberg M. Drought effect on biocrust resilience: High-speed winds result in crust burial and crust rupture and flaking. Science of the Total Environment 2017; 579: 848-59. doi: 10.1016/j. scitotenv.2016.11.016.

9. McKenna Neuman C, Maxwell CD, Boulton JW. Wind transport of sand surfaces crusted with photoautotrophic microorganisms. CATENA 1996; 27(3-4): 229-47. doi: 10.1016/0341-8162(96)00023-9.

10. Kidron GJ. Runoff-induced sediment yield from dune slopes in the Negev Desert, 2: texture, carbonate and organic matter. Earth Surf Process Landf 2001; 26(6): 58399. doi: 10.1002/esp.194.

11. Mugnai G, Rossi F, Felde VJ, Colesie C, Budel B, Peth $\mathrm{S}$. The potential of the cyanobacterium Leptolyngbya ohadii as inoculums for stabilizing bare sandy substrates. Soil Biol Biochem 2018; 127: 318-28. doi: 10.1016/j. soilbio.2018.08.007.

12. Mugnai G, Rossi F, Chamizo S, Adessi A, De Philippis R. The role of grain size and inoculum amount on biocrust formation by Leptolyngbya ohadii. CATENA 2019; 184 : 1-9. doi: 10.1016/j.catena.2019.104248.

13. Belnap J, Lange OL. Biological Soil Crusts: Structure, Function, and Management. Heidelberg, Berlin: Springer; 
2003. doi: 10.1007/978-3-642-56475-8.

14. Grube M, Berg G. Microbial consortia of bacteria and fungi with focus on the lichen symbiosis. Fungal Biology Reviews 2009; 23(3): 72-85. doi: 10.1016/j.fbr.2009.10.001.

15. Hodkinson BP, Gottel NR, Schadt CW, Lutzoni F. Photoautotrophic symbiont and geography are major factors affecting highly structured and diverse bacterial communities in the lichen microbiome. Environ Microbiol 2012; 14(1): 147-61. doi: 10.1111/j.1462-2920.2011.02560.x.

16. Cockell CS, Knowland J. Ultraviolet radiation screening compounds. Biol Rev Camb Philos Soc 1999; 74(3): 311-45. doi: 10.1017/s0006323199005356.

17. Dickensheets DL, Wynn-Williams DD, Edwards HG, Schoen CL, Crowder C, Newton EM. A novel miniature confocal microscope/Raman spectrometer system for biomolecular analysis on future Mars missions after Antarctic trials. Journal of Raman Spectroscopy 2000; 31(7): 633-5. doi: 10.1002/10974555(200007)31:7<633::AIDJRS620 >3.0.CO;2-R.

18. Edwards HG. A novel extremophile strategy studied by Raman spectroscopy. Spectrochim Acta a Mol Biomol Spectrosc 2007; 68(4): 1126-32. doi: 10.1016/j. saa.2006.11.029.

19. Miralles I, Jorge-Villar SE, Cantón Y, Domingo F. Using a mini-Raman spectrometer to monitor the adaptive strategies of extremophile colonizers in arid deserts: relationships between signal strength, adaptive strategies, solar radiation, and humidity. Astrobiology 2012; 12(8): 743-53. doi: 10.1089/ast.2011.0763.

20. Weber B, Budel B, Belnap J. Biological Soil Crusts: An Organizing Principle in Drylands. New York: Springer International Publishing; 2016. doi: 10.1007/978-3-31930214-0.

21. Cheshire MV. Origins ansd stability of soil polysaccharide. Eur J Soil Sci 1977; 28(1): 1-10. doi: 10.1111/j.13652389.1977.tb02290.x.

22. Schlecht-Pietsch S, Wagner U, Anderson TH. Changes in composition of soil polysccaharides and aggregate stability after carbon amendments to different textured soils. Applied Soil Ecology 1994; 1(2): 145-54. doi: 10.1016/09291393(94)90034-5.

23. Chen L, Rossi F, Deng S, Liu Y, Wang G, Andessi A, et al. Macromolecular and chemical features of the excreted extracellular polysaccharides in induced biological soil crusts of different ages. Soil Biology and Biochemistry 2014; 78: 1-9. doi: 10.1016/j.soilbio.2014.07.004.

24. De Philippis R, Vincenzini M. Exocellular polysaccharides from cyanobacteria and their possible applications. FEMS Microbiology Reviews 1998; 22(3): 151-75. doi: 10.1111/ j.1574-6976.1998.tb00365.x.

25. Hu C, Liu Y, Paulsen BS, Petersen D, Klaveness D. Extracellular carbohydrate polymers from five desert soil algae with different cohesion in the stabilization of fine sand grain. Carbohydrate Polymers 2003; 54(1): 33-42. doi: 10.1016/S0144-8617(03)00135-8.

26. Chapman SJ, Lynck JM. Some properties polysaccharides of microorganisms from degraded straw. Enzyme and Microbial Technology 1985; 7(4): 161-3. doi: 10.1016/01410229(85)90057-2.

27. Ehling-Schulz M, Bilger W, Scherer S. UV-B-induced synthesis of photoprotective pigments and extracellular polysaccharides in the terrestrial cyanobacterium Nostoc commune. J Bacteriol 1997; 179(6): 1940-5. doi: 10.1128/ jb.179.6.1940-1945.1997.

28. Bakhshandemehr L, Soltani S, Sepehr A. Assessment of present status of desertification and modifying the MEDALUS model in Segzi plain of Isfahan. Journal of Range and Watershed Management 2013; 66(1): 27-41. doi: 10.22059/jrwm.2013.35326.

29. Rodriguez Caballero E, Escribano P, Olehowski C, Chamizo S, Hill J, Canton Y, et al. Transferability of multiHyperspectral optional biocrust indices. ISPRS Journal of Photogrammetry and Remote Sensing 2017; 126: 94-107. Doi: 10.1016/j.isprsjprs.2017.02.007.

30. Obermayer W. Management of a Lichen Herbarium. In: Kranner IC, Beckett RP, Varma AK. Protocols in Lichenology. Berlin: Springer; 2002. p. 507-23. doi: 10.1007/978-3-642-56359-1_29.

31. Dobson FS. Lichens. An Illustrated Guide to the British and Irish Species. 6th ed. Slough, UK: The Richmond Publishing Co; 2011. doi: 10.1111/j.1095-8339.2012.01226.x.

32. Malcolm WM. Galloway DJ. New Zealand lichens: cheklist, key and glossary. Museum of New Zealand, Te Papa Tongarewa Nelson, Wellungton, New Zealand, 1997.

33. Ryan BD, Bungartz F, Nash III TH. Morphology and anatomy of the lichen thallus. Lichen flora of the Greater Sonoran Desert Region. I. Lichens unlimited. Tempe AZ: Arizona State University; 2002. p.8-23.

34. Ahti T, Sohrabi M. A synopsis of Iranian Cladonia (Lichenes). Flora Mediterranea 2006; 16: 139-44.

35. Awasthi DD. key to the microlichens of India, Nepal and Sri Lanka. J Cramer 1991.

36. Gaya E. Taxonomical Revision of the Caloplaca Saxicola Group (Teloschistaceae, Lichen-forming Ascomycota). J Cramer Verlag; 2009.

37. Krzewicka B. A revision of Verrucaria sl (Verrucariaceae) in Poland. Polish Botanical Studies 2012; 27(3):143.

38. Magnusson AH. Lichens from central Asia, Reports from the scientific expedition to the North-Western provinces of China under the leadership of Dr. Sven Hedin (the Sino-Swedish expedition). XI. Botany. Aktiebolaget Thule, Stockholm, 1940.

39. Nash T, Ryan BD, Diederich P, Bungartz F. Lichen Flora of the Greater Sonoran Desert Region. Tempe, AZ: Lichen Unlimited; 2002.

40. Schultz M, Brown G, Büdel B. Cyanophilous lichens from Kuwait. Nova Hedwigia 2000; 70(1): 193-216. doi: 10.1127/ nova.hedwigia/70/2000/193.

41. Sliwa L. A revision of the Lecanora dispersa complex in North America. Polish Botanical Journal 2007; 52(1): 1-70.

42. Smith CW, Aptroot A, Coppins BJ, Fletcher A, Gilbert OL, James PW, et al. The Lichens of Great Britain and Ireland. 2nd ed. UK: British Lichen Society; 2009.

43. Temina M, Kondratyuk S, Zelenko S, Wasser S, Nevo E. Lichen-forming, lichenicolous and allied fungi of Israel. in: Wasser SP, Nevo Eviatar. Biodiversity of Cyanoprokaryotes, Algae and Fungi of Israel. A.R.A. Ganter Verlag K.-G, Ruggell, Liechtenstein, 1-384. https://www.amazon. de/Lichen-Forming-Lichenicolous-Allied-Israel/ dp/3906166414 
44. Crous PW, Gams W, Stalpers JA, Robert V, Stegehuis G. MycoBank: an online initiative to launch mycology into the 21st century. Studies in Mycology 2004; 50(1): 19-22.

45. Bower CA, Wilcox LV. Soluble Salts. In: Norman AG. Methods of Soil Analysis: Part 2 Chemical and Microbiological Properties. USA: American Society of Agronomy; 1965. p. 167-79.

46. Walkely A, Block A. An examination of the degtjareff method for determining soil organic matter and a proposed modification of the chromic acid titration method. Soil Science 1934; 37(1): 29-38. doi: 10.1097/00010694193401000-00003.

47. Folk RL, Ward WC. Brazos river bar: A study in the significance of grain size parameters. J. Sed. Petrol 1957; 27(1): 3-26. doi: 10.1306/74D70646-2B21-11D78648000102C1865D.

48. Kemper WD, Rosenau RC. Aggregate stability and size distribution. In: Methods of Soil Analysis: Part 1. 2nd ed. USA: American Society of Agronomy-Soil Sci Soci of America; 1986. p. 425-42. doi: 10.2136/sssabookser5.1.2ed. c17.

49. Zobeck TM, Scott Van Pelt R. Wind Erosion. Nebraska, US: Publications from USDA-ARS / UNL Faculty; 2014.

50. Cox RJ, Peterson HL, Young J, Cusik C, Spinoza E O. The forensic analysis of soil organic by FTIR. Forensic Sci Int 2000; 108(2): 107-116. doi: 10.1016/S0379-0738(99)002030.

51. Margenot AJ, Calderon FJ, Goyne KW, Mukome FN, Parikh SJ. IR Spectroscopy, Soil Analysis Application. In: Lindon JC, Tranter GE, Koppenaal DW. The Encyclopedia of Spectroscopy and Spectrometry. 3rd ed. Oxford: Academic Press; 2017. p. 448-54.

52. Margenot AJ, Calderon FJ, Bowles MT, Parikh SJ, Jackson EL. Soil organic matter functional group composition in relation to organic carbon, nitrogen and phosphorus fraction in organically managed tomato field. Soil Sci Soci Am J 2015; 79: 772-82. doi: 10.2136/sssaj2015.02.0070.

53. Margenot AJ, Calderon FJ, Parikh SJ. Limitation and potential of spectral subtractions in Fourier-Transform Infrared spectroscopy of soilsamples. Soil Sci Soc Am J 2015; 80(1): 10-26. doi: 10.2136/sssaj2015.06.0228.

54. Parikh SJ, Goyne KW, Margenot AJ, Mukome FN, Calderón FJ. Soil chemical insights provided through vibrational spectroscopy. Advances in Agronomy 2014; 126: 1-48. doi: 10.1016/B978-0-12-800132-5.00001-8.

55. Acron CJ, Paul EA, Rennie DA. Measurement of the polysaccharide content of soils. Canadian Journal of Soil Science 1963; 43(1): 141-50. doi: 10.4141/cjss63-017.

56. Atansova E, Atansova I. Determination of total polysaccharides in soils affected by forest fires. Bulgarian Journal of Ecological Science (Bulgaria) 2012.

57. DuBios M, Gilles KA, Hamilton JK, Rebers PA, Smith F. Colorimetric method for deterrnination of sunars and rclated substanccs. Anal Chcrn 1956; 28(3): 350-56.

58. Debosz K, Vognsen L, Labouriau R. Carbohydrates in hot water extracts of soil aggregates as influenced by long-term management. Commun Soil Sci Plant Anal 2002; 33(3-4): 623-34. doi: 10.1081/CSS-120002768.

59. Sedgwick P. Pearson's correlation coefficient. BMJ 2012; 345: e4483.
60. Jolliffe IT, Cadima J. Principal component analysis: a review and recent developments. Phil Trans R Soc 2016; A374: 20150202. doi: 10.1098/rsta.2015.0202.

61. Tatzber M, Stemmer M, Spiegel H, Katzlberger C, Haberhauer G, Mentler A, et al. FTIR-spectroscopic characterization of humic acids and humin fractions obtained by advanced $\mathrm{NaOH}, \mathrm{Na} 4 \mathrm{P} 2 \mathrm{O} 7$, and $\mathrm{Na} 2 \mathrm{CO} 3$ extraction procedures. J Plant Nut Soil Sci 2007; 170(4): 522-9. doi: 10.1002/jpln.200622082.

62. Senesi N, D'Orazio V, Ricca G. Humic acids in the first generation of EUROSOILS. Geoderma 2003; 116(3-4): 32544. doi: 10.1016/S0016-7061(03)00107-1.

63. Olk DC, Brunetti G, Senesi N. Decrease in humification of organic matter with intensified lowland rice cropping a wet chemical and spectroscopic investigation. Soil Sci Soc Am J 2000; 64(4): 1337-7. doi: 10.2136/sssaj2000.6441337x.

64. Haberhauer G, Rafferty B, Strebl F, Gerzabeka MH. Comparison of the composition of forest soil litter derived from three different sites at various decompositional stages using FTIR spectroscopy. Geoderma 1998; 83(3-4): 331-42. doi: 10.1016/S0016-7061(98)00008-1.

65. Fernández-Getino AP, Hernández Z, Piedra Buena A, Almendros G. Assessment of the effects of environmental factors on humification processes by derivative infrared spectroscopy and discriminant analysis. Geoderma 2010; 158(3-4): 225-32. doi: 10.1016/j.geoderma.2010.05.002.

66. He Z, Honeycutt CW, Zhang H. Elemental and fourier transform-infrared spectroscopic analysis of water-and pyrophosphate-extracted soil organic matter. Soil Science 2011; 176(4): 183-9.

67. Vergnoux A, Guiliano M, Di Rocco R, Domeizel M, Théraulaz F, Doumenq P. Quantitative and midinfrared changes of humic substances from burned soils. Environmental Research 2011; 111(2): 205-14. doi: 10.1016/j.envres.2010.03.005.

68. Piccolo A, Zaccheo P, Genevini PG. Chemical characterization of humic substances extracted from organic-waste-amended soils. Bioresource Technology 1992; 40(3): 275-82. doi: 10.1016/0960-8524(92)90154-P.

69. Krivoshein PK, Volkov DS, Rogova OB, Proskurnin MA. FTIR photoacoustic spectroscopy for identification and assessment of soil components: Chernozems and their size fractions. Photoacoustics 2020; 18: 100162. doi: 10.1016/j. pacs.2020.100162.

70. Xu X, Du C, Ma F, Shen Y, Zhou J, Forensic soil analysis using laser-induced breakdown spectroscopy (LIBS) and Fourier transform infrared total attenuated reflectance spectroscopy (FTIR-ATR): Principles and case studies, Forensic Science International 2020;310; 110222. https:// doi.org/10.1016/j.forsciint.2020.110222.

71. Bock J, Su GJ. Interpretation of the infrared spectra of fused silica, J. Am. Ceram.Soc. 1970;53 (2): 69-73. https://doi. org/10.1111/j.1151-2916.1970.tb12012.x.

72. Liu D, Yuan P, Liu H, Cai J, Tan D, Zhu J, Chen T. Quantitative characterization of the solid acidity of montmorillonite using combined FTIR and TPD based on the NH3 adsorption system. Appl Clay Sci 2013; 80-81: 407-412. https://doi.org/10.1016/j.clay.2013.07.006.

73. Hofmeister AM, Bowey JE. Quantitative infrared spectra of hydrosilicates and related minerals. Mon Not R Astron 
Soc,2006; 367 (2): 577-591. https://doi.org/10.1111/j.13652966.2006.09894.x.

74. Xing Z, Tian K, Du C, Li C, Zhou J, Chen Z. Agricultural soil characterization by FTIR spectroscopy at micrometer scales: Depth profiling by photoacoustic spectroscopy. Geoderma 2019; 335: 94-103. doi: 10.1016/j.geoderma.2018.08.003.

75. Belnap J, Gillette DA. Vulnerability of desert biological soil crusts to wind erosion: the influences of crust development, soil texture, and disturbance. J Arid Environ 1998; 39(2): 133-42. doi: 10.1006/jare.1998.0388.

76. Gao L, Bowker MA, Xu M, Sun H, Tuo D, Zhao Y. Biological soil crusts decrease erodibility by modifying inherent soil properties on the Loess Plateau, China. Soil Biol Biochem 2017; 105: 49-58. doi: 10.1016/j.soilbio.2016.11.009.

77. Zhao Y, Zhang Z, Hu Y, Chen Y. The seasonal and successional variations of carbon release from biological soil crust-covered soil. J Arid Environ 2016; 127: 148-53. doi: 10.1016/j.jaridenv.2015.11.012.

78. Liu YR, Delgado-Baquerizo M, Trivedi P, He JZ, Wang JT, Singh BK. Identity of biocrust species and microbial communities drive the response of soil multifunctionality to simulated global change. Soil Biol Biochem 107: 208-17. doi: 10.1016/j.soilbio.2016.12.003.

79. Churchman JG, Foster RC, D’Acqui LP, Janik LJ, Skjemstad JO, Merry RH, et al. Effect of land-use history on the potential for carbon sequestration in an Alfisol. Soil \& Tillage Research 2010; 109(1): 23-35. doi: 10.1016/j. still.2010.03.012.

80. Kakeh J, Gorji M, Sohrabi M, Tavili A, Pourbabaee AA. Effects of biological soil crusts on some physicochemical characteristics of rangeland soils of Alagol, Turkmen Sahra, NE Iran. Soil Tillage Res 181: 152-9. doi: 10.1016/j. still.2018.04.007.

81. Li B, Gao J, Wang X, Ma L, Cui Q, Vest M. Effects of biological soil crusts on water infiltration and evaporation Yanchi Ningxia, Maowusu Desert, China. International Journal of Sediment Research 2016; 31(4): 311-23. doi: 10.1016/j.ijsrc.2016.05.005.
82. Chepil WS, Woodruff NP. The physics of wind erosion and it's control. Advances in Agronomy 1963; 15: 211-302. doi: 10.1016/S0065-2113(08)60400-9.

83. Tsoar H, Bagnold RA. The physics of blown sand and desert dunes. Progress in Physical Geography: Earth and Environment 1994; 18(1): 91-96. doi:10.1177/030913339401800105.

84. Roman JR, Chilton AM, Canton Y, Mu-noz-Rojas M. Assessing the viability of cyanobacteria pellets for application in arid land restoration. J Environ Manage 2020; 270: 110795. doi: 10.1016/j.jenvman.2020.110795.

85. Swincer GD, Oades JM, Greenland DJ. The extraction, characterization, and significance of soil polysaccharides. Advances in Agronomy 1969; 21: 195-235. doi: 10.1016/ S0065-2113(08)60098-X.

86. Madejova J. FTIR techniques in clay mineral studies. Vibrational Spectroscopy 2003; 31(1): 1-10. doi: 10.1016/ S0924-2031(02)00065-6.

87. Farmer VC. The Infrared Spectra of Minerals. UK: Mineralogical Society of Great Britain and Ireland. doi: 10.1180/mono-4.

88. Dontsova KM, Norton LD, Johnston CT. Calcium and magnesium effects on ammonia adsorption by soil clays. Soil Sci Soc Am J 2005; 69(4): 1225-32. doi: 10.2136/ sssaj2004.0335.

89. Fripiat JJ, Leonard A, Uytterho JB. Structure and properties of amorphous silicoaluminas. II. lewis and brønsted acid sites. J Phys Chem 1965; 69(10): 3274-9. doi: 10.1021/ j100894a009.

90. Mortland MM, Raman KV. Surface acidity of smectites in relation to hydration exchangeable cation and structure. Clays and Clay Minerals 1968; 16(5): 393-98. doi: 10.1346/ CCMN.1968.0160508.

91. Bernier MH, Levy GJ, Fine P, Borisover M. Organic matter composition in soils irrigated with treated wastewater: FT-IR spectroscopic analysis of bulk soil samples. Geoderma 2013; 209-210: 233-40. doi: 10.1016/j.geoderma.2013.06.017. 